\title{
Depressão: expressões na infância 30
}

\section{Audrey Setton Lopes de Souza ${ }^{31}$}

Gostaria de iniciar a conversa falando sobre o título da mesa. Inicialmente me convidaram para uma mesa sobre depressão na infância e minha primeira resposta foi que, apesar de mais de 40 anos de experiência no trabalho com crianças, não poderia dizer que tive muito contato com crianças deprimidas no sentido mais usual do termo, então não poderia colaborar. Mas, me debatendo com esta ideia, fui me dando conta que a forma de expressão da depressão ou de aspectos depressivos em crianças se apresentava das mais variadas maneiras e que poderia colaborar para expandir a compreensão sobre o que seria um debate bastante rico.

Cito, para começar, apelando para o Manual de Psicopatologia infantil, Ajuriaguera (1986) quando aborda o tema:

"Quando se evoca a depressão na criança, existe um contraste entre a extrema referência teórica e a grande raridade do quadro clínico, pelo menos em seu aspecto adultomórfico" (pag 290).

Então, a depressão, como sintoma na infância, pode se manifestar, sim, por um lado, como apatia, auto depreciação, sentimentos de não ser amado pelos pais e pelos amigos, mas também como, agitação, hiperatividade, dificuldades de aprendizagem, mentiras, comportamentos anti-sociais, agressividade ou mesmo sintomas hipocondríacos.

Início pela importância da depressão na referência teórica: pretendo sublinhar a "depressividade" como conquista e, neste sentido, a fuga dos sentimentos depressivos como um empobrecimento pessoal. Aí estaria a grande questão do desenvolvimento psíquico, como viver a depressividade sem ser vencido por ela e sucumbir à depressão ou ter que recorrer a maciças defesas para não entrar em contato? Este é o campo que gostaria de explorar para abordar as diversas manifestações da depressão na infância.

\footnotetext{
30 Trabalho apresentado na mesa "Depressão: expressões na infância" no II Simpósio Bienal SBPSP "Fronteiras da Psicanálise: a clínica em movimento" no dia 22 de agosto de 2020.

${ }^{31}$ Membro efetivo e docente da SBPSP, professora aposentada do IP-USP, Doutora pelo IP-USP, professora do curso de Psicanálise com crianças do Sedes Sapientiae.
} 
Para começar a conversa, podemos destacar que, assim como apontou Freud, existe uma articulação entre o luto e a melancolia, mostrando que, no luto normal poderíamos encontrar sentimentos próximos àqueles encontrados em indivíduos deprimidos (um estado de humor triste, um recolhimento e falta de interesse no mundo circundante), mas na melancolia existiria uma forma de ataque ao próprio eu, uma espécie de depreciação de si mesmo que ele, brilhantemente, como sempre, buscou compreender iluminando questões que, no melancólico impediriam a elaboração "normal" do luto.

Quando estamos no campo do infantil precisamos destacar a importância da elaboração do primeiro grande luto: a percepção da mãe como um objeto separado, com todas as angustias daí decorrentes, a perda da onipotência infantil, o medo da perda real deste objeto amado, a culpa, a responsabilidade, a preocupação ("concern"). Vários autores têm se ocupado com a noção do objeto ausente e pelo desenvolvimento da capacidade de manter a confiança na permanência do objeto amado, mesmo quando este está fora do campo perceptivo da criança, destacando-a como vital para a capacidade de desenvolver o simbolismo, suportar e sobreviver às várias perdas inerentes ao desenvolvimento. (Freud, Klein, Winnicott, Bion).

Melanie Klein iluminou teoricamente este momento, como posição depressiva, referindo-se a um período inicial do desenvolvimento e, sensível clínica como era, não deixou de destacar a possibilidade do uso de mecanismos maníacos e obsessivos, como fazendo parte deste difícil e rico processo.

Fiz este pequeno percurso para destacar a importância desta conquista, da elaboração da percepção da mãe como objeto separado, da existência do outro, como primordial para o desenvolvimento que, como destacam, cada um à sua maneira, vai permitir que esta separação seja elaborada. Klein vai destacar a importância da introjeção do bom objeto com segurança para que este processo se inicie e sabemos que uma experiência inicial de segurança nestas primeiras relações será sempre primordial.

Vou resistir à tentação de seguir ..... neste caminho da depressividade como aspecto teórico e caminhar agora nas manifestações psicopatológicas.

As manifestações depressivas, no trato destas separações já foram abordados por autores como Spitz e Bowlby. 
Spitz relatou o que chamou de depressão anaclítica, como uma reação à perda repentina do apoio materno em bebês de 6 a 18 meses, colocados em ambientes desfavoráveis, após uma separação brutal da mãe: ele relata um período inicial de choramingo e depois um estado de retraimento e de indiferença além de regressões no desenvolvimento e sintomas somáticos.

Bowlby também se debruçou sobre as reações das crianças frente à uma separação materna e apontou para uma espécie de sequência de comportamentos: uma fase de protesto ( criança fica agitada, chora, se debate), após este período, surge uma fase de desespero (como um estado de luto, se recusa a comer, fica mais fechada etc) e em seguida surgiria a fase do desligamento (não mais recusa ajuda e parece aceitar a ausência) ele destaca a importância de discriminar entre reações à separação e depressão.

Cito estes autores para destacar a importância de estarmos atentos a estas manifestações que precedem a depressão propriamente dita oferecendo uma escuta a estas manifestações como agitação, agressividade, ou mesmo atitudes onipotentes e desafiadoras, podendo encobrir a emergência de estados depressivos. Considero também bastante úteis, clinicamente, as considerações de Anne Alvarez da distinção entre estados maníacos que são uma negação da depressão e estados que sinalizam uma recuperação da depressão (2020, pag.215) e a ênfase na presença viva da mãe e da terapeuta. E de Bick. que mostra como na ausência da continência materna, nos primeiros tempos do desenvolvimento as crianças poderiam apelar para outras formas de sustentação que poderiam aparecer como um excessivo desenvolvimento muscular ou ainda tornando-se precocemente auto suficiente e controlador ou excessivamente agitado, ou uma espécie de fixação adesiva à mãe.

Winnicott fala por ex. da tendência antissocial como um pedido de socorro contra angustias depressivas, ligada a experiências de privação, assim, ouvir como socorro e esperança, manifestações de mentiras sucessivas e pequenos roubos nos permite acolher clinicamente estas crianças e ajuda-las nesta elaboração.

João ( 5 anos) tinha acabado de ganhar dois irmãozinhos gêmeos e seus pais me procuraram pois ele passou a ter muitos medos, além disso tinha um comportamento autoritário e mentia frequentemente. Recebi um menino arrogante e autoritário, mas que precisava passar sessões e mais sessões 
preparando armadilhas para quem fosse entrar na minha sala. Comigo pode conversar do que chamava de suas "maluquices" para lidar com a perda deste lugar narcísico de primeiro filho, primeiro neto e reizinho da casa que ocupava antes do nascimento de seus irmãos. Ele não estava fenomenologicamente deprimido, mas seus comportamentos revelavam o medo de viver suas angustias depressivas, a sensação de ter ficado sem lugar, a angustia em relação a suas fantasias destrutivas em relação aos irmãos e aos pais, além da luta com esforços obsessivos para evitar a emergência de suas "maluquices".

Joana (7 anos) pediu a seu pai para que a levasse a um psicólogo, ele quis entender por que, pois, ela lhe parecia bem. Ela disse que andava tendo vontades e às vezes roubando objetos de seus amigos e que achava que precisava de uma ajuda de uma psicóloga para poder conversar. Ela perdera a mãe há mais ou menos 1 ano, em circunstâncias bastante difíceis, seu pai se ocupava dos filhos da melhor maneira que podia, mas ela sentia que não havia espaço para conversar com ele sobre esta dor. A análise foi seu espaço para viver esta dor.

Roberto já manifestava expressões mais próximas do que conhecemos como depressão. Tinha dificuldades no relacionamento com os amigos e achavam que estes não gostavam deles. Roberto se recusava a fazer contato com os outros, dizia preferir ficar sozinho. Precisei "reclamar" muito sua presença, mostrar muito meu empenho por encontra-lo, para que ele fosse diminuindo os períodos nos quais ia para o que chamávamos de seu esconderijo. Aquilo que era, virar de costas para mim e ficar com suas revistinhas, passou a ser, brincar de escondeesconde e pedir para ser procurado e encontrado. Precisávamos construir a segurança de ter um lugar na minha vida e na vida das pessoas a sua volta. Interessante contar que seus pais relatam que tinham muito medo de não saber consolá-lo quando ele era pequeno, seu choro desesperado, desesperava seus pais.

Espero ter conseguido com estas breves vinhetas clínicas iluminar diferentes formas de expressão da depressão na psicanálise com crianças.

Antes de finalizar gostaria de contar como, ao menos no início da pandemia, muitas crianças diziam a seus pais que estavam gostando deste tal Corona vírus pois agora o papai e a mamãe estavam muito mais em casa com eles. É bem verdade que muitos pais se desesperaram com o excesso de demandas deste 
período, mas também não podemos deixar de escutar estas mensagens de seus filhos. 